\title{
Evaluation of Coffeehouse Spaces' Interior Design Through Phenomenological and Ocular-Centered Methods
}

\author{
Didem Erten Bilgiç ${ }^{1 *}$, Esmahan Betül Şahin² \\ ${ }^{1 *}$ Kocaeli University, Faculty of Architecture and Design, Departmant of Interior Architecture, Kocaeli, Turkey, (ORCID: 0000-0002-6304-8648), \\ didemerten@gmail.com \\ ${ }^{2}$ Kocaeli University, Sosial Science Enstitute, Kocaeli, Turkey, (ORCID: 0000-0001-8924-333X), esbetul@hotmail.com
}

(First received 12 February 2021 and in final form 21 April 2021)

(DOI: 10.31590/ejosat.879248)

ATIF/REFERENCE: Erten Bilgiç, D., Şahin, E.B., (2021). Evaluation of Coffeehouse Spaces' Interior Design Through Phenomenological and Ocular-Centered Methods. European Journal of Science and Technology, (23), 769-780.

\begin{abstract}
The perception of space is related to the consumer experiencing in the space and remembering the space. The ocular-centered perspective of modernism has created aesthetic forms far from experience with a completely relative understanding of beauty for the space designer and the space user. However, it is possible to perceive and gather information about space in memory beyond the five senses; vitalness, space-subject interaction, sensation, experience, movement, time, and subjectivity. Phenomenology is the focal point of these spatial practices. In this study, the consumer's effective roles in the perception of space have been investigated through ocular-centrist and phenomenological methods. To obtain data, study areas were determined, therefore, coffee presentation-sale areas were chosen as the study area. The continuation of the study identifies the historical district of Beyoglu as the location of five coffeehouses. Moreover, a questionnaire was conducted upon the twenty people who have experienced those coffeehouses to infer how they perceive and remember their space-design. The questionnaires inquire into the comparison between spaces that include perception elements beyond the five senses and the spaces that include solely the visual perception elements to understand the preferences of the consumers and which space type leaves a positive and permanent impression in their memory.
\end{abstract}

Keywords: Ocular-centrism, phenomenology, space, coffeehouse, Istanbul- Beyoglu.

\section{Kahve Mekânları İç Mekân Tasarımının Fenomenolojik ve Gözmerkezci Yöntemler Üzerinden Değerlendirilmesi}

\section{Öz}

Mekân algısı, kullanıcının mekânda deneyim kazanması ve bu doğrultuda hatıllanması ile ilgilidir. Modernizmin gözmerkezci bakış açısı zaman içinde hem mekânı tasarlayan hem de mekân kullanıcısı için tamamen göreceli bir güzellik anlayışı ile deneyimden uzak estetik formlar oluşturmuştur. Ancak mekânı algılama ve bellekte mekâna dair bilgiler toplama; beş duyunun ötesinde, yaşamsallık, mekân özne etkileşimi, duyum, deneyim, hareket, zaman ve öznellikle şekillenerek mümkündür. Bu mekânsal pratiklerin odak noktasını fenomenoloji oluşturur. Makalede, gözmerkezci ve fenomenolojik yöntemler aracılığı ile kullanıcının mekânı algılamadaki etkin rolleri araştırılmıştır. Araştırmada veri elde etmek için çalışma alanları belirlenmiş ve inceleme alanı olarak kahve sunum-satış alanları seçilmiştir. Çalışmanın devamında kokusu ile herkesin belleğinde anılarını çağrıştıran kahvenin, İstanbul'un Beyoğlu semtinde seçilen beş kahve mekânı ve bu mekânları deneyimleyen yirmi kişi üzerinde mekânları nasıl algıladıklarına ve mekân tasarımlarına ilişkin hatırladıklarına yönelik anket yapılmıştır. Çalışmada sorgulanan durum; mekânı algılamada beş duyumuzun ötesinde duyum ve deneyime dayanan algı öğelerini barındıran mekânlar ile görsel algıya dayanan öğeleri barındıran mekânların kullanıcıların tercihleri açısından karşılaştırılmasının yapılması ve kullanıcı hafızasında hangi etkileri bıraktığını anlamaktır.

Anahtar Kelimeler: Gözmerkezcilik, fenomenoloji, mekân, kahvehane, İstanbul- Beyoğlu.

\footnotetext{
* Corresponding Author: didemerten@gmail.com
} 


\section{Introduction}

A person perceives and interprets the space in which she or he is located and interprets this space. The perception of space is shaped by the knowledge, culture, and environment of the subject from her or his past life. While this situation reveals the subjectivity of the perception of space, space is also effective in shaping the actions and experiences of the subject per se. The perception that shapes space-subject interaction and which is the common research subject of many disciplines is defined in Dr. Feriha Baymur's book titled "General Psychology" as "the stimuli transmitted to the brain through the sensory organs which turn into sensations and organize and gain meaning in various aspects." (Baymur, 1976: 125). Psychologist Clifford T. Morgan, who came up with a similar definition in his book titled Introduction to Psychology defines perception as "the process of interpreting senses and making them meaningful. People perceive the world through all sensory organs, so they have perceptions about every situation such as visual perception, auditory perception, and others" (Morgan, 1981:261). Because the life of each person is shaped individually and sui generis, people interpret the same stimuli differently and therefore their perceptions differ from each other.

\section{Material and Method}

In this study, first of all, theoretical explanations were made on the definitions, emergence, and revealed differences of the ocular-centric and phenomenological methods in the perception of the architectural space. Then, according to the data obtained from the results of the questionnaires conducted with the selected topic, the locations, and subjects suitable for the topic, information about the preference of the spaces for the consumers and the interior design criteria were analyzed.

As a result of this research, judgments were made on the preference of coffeehouse places according to the interior design incidental to the perception criteria determined by phenomenological and ocular-centric methods, whether the located structures have historical value or not and how they have an impact in terms of affirmative and adverse aspects on the perception experience of the consumer are determined. Derived from the results obtained, evaluations have been made on the perception of interior design that full success can be achieved in the design and consumer satisfaction only if there is a genuine sensory experience not only with the sense of vision but also in subjective integrity with the body and soul.

\section{Ocular-Centric and Phenomenological Approach in The Perception Of Space}

The perception of the architectural space is realized through the design created by the coexistence of the floor, wall, ceiling, and all the fittings that fill the void created by that space. It is an ocular-centered method of perception that the design of the space is perceived primarily and with a high level of vision. In this method of perception, only the brain that the eye sees are recorded first and those that are not seen are ignored. Ocular centrism is also referred to in the international literature related to the terms "bodiless eye", "eye of the mind", "unfocused perspective". An ocular-centrist approach is an approach that degrades the subject to the eye which only watches. The subject has a perception that is far from experiencing and feeling the space, disconnected from its body, with the eyes of the mind, accepting only what it sees, ignoring what it doesn't see. From this perspective, architecture is solely considered as a figure of the eye.

Within the context of the ancient age sight theories, objects are not connected to each other and to the coordinates of the space they are into the contrary of perspective, but rather they seem to be collocated in a finite container. The integrity and harmony in the Renaissance perspective is the stage where the way of seeing and the sense of space fuse together with the experience of space. Aesthetic and theoretical space unite and integrate in perspective and reshape the perceived space. In other words, the representation modality of sight and objects in art is parallel to the philosophical worldview (Panofsky, 1991: 44).The ocular-centered approach, which reached its climax with modernism, ignores the existence of the senses and suggests that information can merely be accessed by reason. The idea of seeing through the eyes of the mind, which privileges vision over the other senses and ignores bodily sensations, is dominant. Establishing an objective relationship with the environment, the observer attains and reaches information through the eyes of the mind. The visual perception criteria determined by this ocularcentered view of modernism for the perception of space are based on the law of Gestalt, which examines the form and proportion created by the parts that make up the form. This law contains concrete rules based on vision. The parts that make up the whole are more meaningful than they individually express. Gestalt law aims to create a simple order based on the shapeground relationship of the perceived forms. Since modern architecture uses these criteria to reveal the most aesthetic form, these spaces, which are disconnected from time and movement phenomena designed with an aesthetic understanding that is only pleasing to the eye, create instantaneous effects and are not included in the observer's memory. As explained by Altıparmakoğlu and Güreni from Hillier and Hanson's research, essentially focused on the spatial experiences of people allows for concrete expression and analysis of abstract characteristics of space that plays the most significant role in creating information based on experiences as a reflection of space in the human mind (Altıparmakoğlu; Gürani,2021:345). It is necessary to examine this information in terms of phenomenology.

Although phenomenology was used in different meanings by philosophers such as Kant, Hegel, Bergson in the history of philosophy, Phenomenology is the philosophical view developed by Edmund Husserl (1859-1938). Husserl developed phenomenology as a philosophical method that postulates to retrace to the preliminary and principle meanings of beings (İnceoğlu, 1999). Dating from 1965, the ocular-centered perspective based on objective and visual concerns began to be questioned and a quest was embarked on for another modern architecture within the scope of the architectural community. Martin Jay was the first to criticize the perception of space using the ocular-centered method. Thee criticism explained in Downcast Eyes- The Denigration of Vision in TwentiethCentury French Thought in addition to the problem expressed by Jay is more than the dominance of the eye. The observer space in the position of a bodiless viewer began to perceive the space as a photograph, graphic design element, and this was valid not only for the perceiver but also for the designer. While designing the space, the designer aimed to make it an image that would create a striking effect. Adolf Loos, who is also a Modernist, opposes watching the space and turning it into photographic space. According to Loos, "a place designed to be experienced will not 
appear nice in photographs. Because for such spaces it is intended that people feel and experience the sensory atmosphere with their five senses physically" (Loos, 2018: 11). In an ocularcentered perspective, space is considered within an eyewink just like a single photo frame. From these judgments, it is seen that the questions such as the value, meaning, and existence of the space beyond the physical definitions of the spaces in the field of architecture are faced with a situation similar to the pursuits of the human beyond its mere physical existence. Approaches using the phenomenological method in the field of architecture and phenomenology in the field of philosophy seek answers to these questions. Phenomenology is not seen as a discipline of philosophy for architecture, but as a method that enables the questioning of the meaning of the architectural form and the understanding of intertwined relations between human beings and the environment (Bognar, 1985: 183-201). Description of perception and essence of the conscious along with the experience that arises in the combination of thought and perception constitutes the subject of phenomenology.

In the sequel of the criticism of modern architecture, space began to be evaluated by a dint of phenomenological method in terms of the vitality, the integration of space and the subject, perceptions shaped by sensation, experience, movement, and time. Phenomenology rejects the idea of absolute perception through the eye and movement has an ascendant ground in relation with perception of space. Space shapes the perception whilst being experienced with the movement of the subject. An experienced space creates an infinite space perception with time. In this sense, phenomenology has shown that the connection of the subject with the world can be achieved by being purified from all sorts of presuppositions brought by the natural sciences and establishing a new category of consciousness and being.

\section{Determination of Experimental Platform of Theoretical Infrastructure and Evaluation Criteria}

Coffee, which started to be consumed among the Sufis in Yemen in the 15th century, has spread rapidly in the east and has shaped the social and communal relations. The Viennese introduced the coffee thanks to the coffee sacks left by the army as a consequence of the defeat of the Ottoman Army in the Siege of Vienna in 1683 (Gürsoy, 2005: 40). The foundations for the recognition of coffee first in Europe and then in America are based on this link-up in Vienna. With the spread of coffee among the communities, coffeehouses, which emerged as places to drink coffee, were first encountered in the Middle East, and later spread over throughout the world and became a part of social life. Following America's acquaintance with coffee, coffee has gained global value rather than merely a flavor.

In coffeehouses, besides entertainment and socialization, diversified exchange of ideas and public discussions are also held. Unlike taverns and churches, such exchange is shared with more vivid consciousness due to the effect of coffee. In Europe and America, men interested in fields such as politics, commerce and culture came to coffeehouses and started drinking coffee. In the course of time, the coffeehouses frequented by everyone started to multiple and spread out preserving their unique culture and space design.

Cafes and coffee places, which have a deep-rooted history, have become an indispensable part of daily life and they are living quarters today. It has been decided to distinguish coffee places as the experimental platform of the research, as they provide a suitable field to examine the sensations, spatiality, belonging, bonding which phenomenology presents us and to analyze how people are affected in the realm of social, cultural and communal life.

The chosen region which is appropriate to provide tangible data for the experimental platform has become the Beyoglu district in Istanbul. Cafe culture first emerged in Turkey in Beyoglu which served as a bridge for coffee to spread out in Europe. Beyoglu, which is Turkey's gateway to the world is the place of residence for a large number of non-Muslims and community members of diverse ethnic groups thus it is a district in which the effects of changes in the world can be observed in a quick and crystal clear manner. Today, with the impact of globalization, it is observed that coffee places in the world have evolved to hubs of consumption and the number of cafes has multiplied in Beyoglu district likewise. At the same time, this region is one of the significant places in Istanbul where the historical background is preserved, and it has been observed that coffee places that can be evaluated and assessed in a phenomenological sense are frequently located in this region. For this reason, five cafes have been selected in Beyoglu as it is decided as the region where the fieldwork will be conducted. These cafes, which are most preferred due to their location are also exclusively chosen because they have distinguished features from each other, and they reserve and shelter evaluation criteria at different rates. These cafes were experienced by a group of twenty people and a questionnaire was made to qualify how they perceive and remember the place a month after the day of the experience. Before examining the coffee places, the criteria of the place experienced with the ocular-centric and phenomenological method were determined by obtaining information from the previously conducted theoretical studies.

\subsection{Determination of Interior Evaluation Criteria by Ocular-centric Method}

Ocular-centrism is a tradition that renders the subject as a viewer privileging vision over the other senses. This tradition, which advocates that knowledge can only be accessed by reason defends that mind is superior to all senses and experiences and acknowledges the eye as the eye of the mind and not as a sense organ. By means of the knowledge and technology used by modern architecture, the domination of the spaces perceived from the ocularcentric point of view that objectifies the human revealed itself. For this reason, space evaluation criteria determined by using the ocular-centric method have the values in common with modern architecture. In this context, the items expressing the space perceived by the eye-centered method are defined as follows.

Rationality indicates that successful architecture should be focused on reason and efficiency. Rationalism is the basis of ocularcentrism as it is an indicator of the correlation between mind, eye and mathematical ratio. It is based on the conception that what is rational will satisfy mentally in the most efficient manner abiding by solid geometric form and mathematical proportions and thus the most aesthetic and accurate architecture will be obtained (Erkartal, 2014: 25-27).

Regarding Viewer may also be expressed as sightoriented or objectifying. Modernist architects design the space through visual perception. It is also referred in Le Corbusier's Modulor and the "Gelstalt Laws" used for the beautiful form that the space was designed for a photo frame with two dimensions 
in mind. The subject is indeed a viewer distant from physical perception and experience.

Static refers to the space, which is a spectacular object, independent of the environment. The space must be stationary in order to perceive it in the most accurate way without being affected by the environment or human. In fact, it is observed that modern spaces are often designed with the idea of a beautiful shot from a photo frame or from a single perspective.

Form expresses simple geometries suitable for standardization such as spheres, cylinders and cones for modern architecture. According to Le Corbusier (1887-1965), one of the important representatives of modern architecture, "the architect's task is to equip the world with these forms by measuring the universal order forms and cubes, cones, spheres, cylinders, or pyramids are major fundamental forms... the images of the forms are evident within us, their tactility is not ambiguous. They are manifestations of the sublime order of the universe, and therefore in harmony with our inner world" (Ojalvo, 2012: 177).

Outsideness concept is the opposite of insideness concept which geographer Edward Relph (1944-...) expresses whilst defining "place". Outsideness involves the feeling like an alien and uneasy in a place as opposed to insideness. In the modern world, people are deterritorialized therefore they are distanced from the relationship between the place and insideness. Relph also considers outsideness as a loss of authenticity (Kartal, 2015: 90-91).

Universality connotes that together with the mass production introduced by the Industrial Revolution, modernism reveals common aesthetic values for the whole world by means of perfect forms and proportions. The objective judgment of modernism speaks of a universality that dedifferentiates all people. It imposes a universal design approach that is based on efficiency and function incidental to Gelstalt principles and modulor ratios, distanced from localities and cultures. This situation implies uniformization and standardization.

Structure is seen to be clear of architectural ornament as an aesthetic value in modern architecture and the functions of the building elements are integrated and rigid. The visualization of the building elements with their structural functions is a moral value of modern architecture and is evaluated with an ocularcentrist approach.

By means of Abstractionism it is aimed to reach a visually perfect place and space. In the modern understanding where the integrity of the building gains importance, the function of exposed concrete and white wall and structural elements such as scaffolding, columns, beams emerges. Thus, the most appropriate architecture is its abstraction by identifying the function of each building element in a visible manner (Erkartal, 2014: 31).

Finished by construction depicts places and spaces where the living people do not make changes according to the needs that arise with the ongoing life in the space after the building was built or an interior space was designed. In other words, it is the preservation of the designed space as it was built without any subjective arrangement arising from life experience or additions according to need.

Absolute Space refers to the same absolute perception valid for everyone which is idealized with abstract and geometric forms of space designs based and centered on ocularcentrism. It evaluates people in a passive position independent of experiences.

Functionality makes mention of a productivity-oriented perspective. Louis H. Sullivan (1856- 1924), known as the first
American modern architect enounced the slogan of "form follows function" (Leland, 2006: 592), which led to definition of every form by function in modern architecture.

Isolation is contemplation of modern constructions independent from the region it is located in during the stage of designing and building without questioning its relation with the surrounding environment.

New (Non-concrete, unsubstantial artificial material) refers to two separate meanings: Firstly, it is a sort of architecture that reacts to past styles and aspires to create new forms, along with the construction techniques and materials introduced by industrialization. Secondly, reference is made to places distant from ageless and timeless feeling of experience with the returns of industrialization in addition to new construction techniques and the use of glass, concrete, steel, plastic-based materials.

Machine Aesthetics; beauty which is a subjective concept is reduced to a universal aesthetic perception which can be measured by objectivizing the concept. Based on Le Corbusier's promise that "a house is a machine for living in" (Leland, 2006: 627), the aesthetics of the rational and simple architectural understanding, referring to the machines, is suitable for mass production and standardization.

\subsection{Determination of Interior Evaluation Criteria by Phenomenological Method}

For creating a space in a phenomenological sense, space must leave a trace in the memory. Memory is the ability to store history and reveal it if desired and creates an important data source in sensing space. Space transforms into codes in memory with perception, reminiscence, experience, and sensations and is recorded in long-term memory. The more context space contains for the individual, for longer it can last in memory. (Turgay, 2018: 156). The concept of space and the image of the space formed in one's mind are very important in terms of connecting with the past by remembering our memories together with the spaces in our minds. Although each and every person is situated in many places throughout her/his life, only certain places leave a trace in her/his memory. The long-term memory of spatial information is related to the relationship between space and subject as a result of one's relationship with space, sensuality and perceptual processes, as well as the social and cultural accumulative experience of the person. When talking about memory, it is necessary to mention not only the memory of the individual, but also the existence of a social memory emerging with the tradition and culture inherited from past life. The architecture of a building carries the contents of the social life of its period. Thus, people experience emotional relationships with people from the past, time difference disappears and those people virtually become part of our lives. (Soykan, 2008: 38-39).

The items expressing the perception of space with the phenomenological method by leaving a trace in memory are described below.

Aura; refers to the uniqueness of the space, it is the feeling of belonging to that moment and of being unique. It should be considered as the "aging mark" attached to the space and the "temporal layers" that occur in the space. Aura makes reference to the transition of the space to the spatial state through connection of the place with the present, remembrance of the past and sensation of the future. Heidegger states the difference between "space and spatiality" in his work titled "Being and Time" by saying that "... space includes the measurable, calculable dimensions of linear orientations, and the substance of 
space is the extensions within this void. The notion of spatial, on the other hand, reflects the mode of comprehending space with practical information that brings the sense of belonging to the state of consciousness, Dasein to go beyond itself and recognize its genuine reality; it is indeed the space we live in." (Aydınlı, 2008: 150-161).

Atmosphere is the first impression of a structure and the intuition created on behalf of a person. Swiss architect Peter Zumthor $(1943-\ldots)$ refers to "qualified architecture" while designating the expression of atmosphere. He denominates qualified architecture in a manner that the architecture has an impact on the subject and stimulates the subject's senses. The atmosphere focuses on the actual experience at the moment, the concept of space and feelings.

Concept of Place expresses the connection between the subject and the space through the concrete space, personal experience and sensations. "Space" and "place" are words used interchangeably in daily life, but when evaluated in a phenomenological sense, they express different concepts in terms of subject-space interaction. The transformation of space into place emerges following the emotional connection established between a person and space.

Bodily Sensation; Heidegger refers to experiencing the space instinctively through the body and the senses, which he calls "poetic measure". Heidegger states that the concept of (poetic) measure is related to the experiences of the person rather than the geometric dimensions. The measurement mentioned by Heidegger depends on the senses, imagination, person's ability to grasp and her/his emotions. He states that with bodily measurement, the person is instinctively integrated and feels familiar with space (Sharr, 2007: 82). As a result of spatial experience, when we look at those who remain in memory over time, it is seen that the vast majority of physical and objective elements are lost, experiences and genuine life experiences remain in memory.

Space-Subject Interaction refers to signification of space in a subjective manner together with time effect and sensations, movement comprehended with the experiencing body rather than merely watched object. The subject is the integration of the space, that is, the sensation of the space by feeling, smelling, touching, grasping with the body, and moving around the space very sensuously. Thus, the subject connects with the space she/he experiences rather than being a viewer.

Movement in the perception of space shapes the relationship that people establish with each other and with the space over time and ensures that each time they have different expressions about the space. This situation necessitates the movement within the space with the concept of time. Thus, the space becomes a "place" experienced with the events and actions that are experienced rather than being the object being watched. Experiencing space gains meaning through actions and movements that center the human body. In her work, "Ways of Seeing", Zevi described the concept of time-space as "the angle of view that keeps pace with each other," and added a fourth dimension namely time dimension to traditional three dimensions. Zevi expresses the fourth dimension with the words: "No architectural work will be fully explained unless the part of the time required to walk around the buildings is taken into account." The subject, acting within the space and looking from a new point of view, explains the concept of time through the actions within the space with the expression "it creates the fourth dimension itself and gives the space its holistic reality by doing so" (Zevi, 2015: 11-23).
Soul of the Place is the feature that distinguishes a space from others and gives life and originality. The soul of the place appears necessarily with environmental factors. The position of the sun is shaped by variables such as climates, day and night difference. (Kartal, 2015: 68).

Critical Regionalism; architectural theorist Kenneth Frampton (1930-...) emphasized the idea of critical regionalism regarding the place. He reveals a local cultural response and resistance to the modernization of the world with universal values, with this thought. It emphasizes the necessity to make designs while maintaining its nature-related structure, in line with the character of the place, and considers it a moral stance against the devastating effects of globalization. (Kartal, 2015: 71-74).

The identity of the place and the feeling of being inside; Edward Relph focuses on the identity of the place, focusing on the identity of the place and the identities that people acquire with the influence of that place. Being inside the place includes belonging to the place, being safe, identifying with the place. The interactions between the place and the subject and the meanings attributed to these interactions have been theorized as 'locality' (Kartal, 2015: 88-91). The feeling of being inside contains a sense of inwardness, intimacy, safety, longing, sense of being here, memory, and authenticity.

Settlement; Heidegger wrote the idea of settlement on the concept of place. The idea he emphasizes in the text "To Build, To Settle" means that a building will not end with building in one go, but building and housing are a whole of continuing actions in a whole way.

Relative Space; rejects idealisation of the space in abstract and geometric forms. It refers to the subjective perception of the experienced individual in interaction with the space. Relative space expresses a dynamic, holistic, multidimensional space perception. This is more than an absolute sense of space, an ambiguous spatial experience is felt. This ambiguity causes an infinite spatial image to be created in the human mind, that is, the individual re-creates the space by experiencing it at different times. It is the explanatory time of the endless image of a single space in memory.

Multi-Sensory Experience; in order for the space to be in the subject's memory, multi-sensory experience is needed. The more senses a space stimulates, the more it connects with the subject.

Unlike the eyes of the mind, bodily vision from these senses refers to re-qualifying the eye as a sense again. In the ocularcentered approach where the subject is the viewer, the observer cannot experience the space. Bodily vision, on the other hand, refers to the essence of the eye (bodily eye), to rethink the eye as a sense again.

Touch, which is a stimulus in perception of space, is important in human-space interaction. According to anthropologist Ashley Montagu, "Skin is the oldest and most sensitive organ. There is even a transformed skin layer on the mesh layer above the eye. Touch is the mother of all senses and has turned into other senses and has differentiated." (Çakıcı Alp and Erkan Yazıc1, 2017: 65) With the increase in social relations between the communities, new spaces needed have revealed new building types over time. Stone, wood, brick and glass, which have been used as building materials since the early ages, allowed production in limited sizes due to the production conditions and technological possibilities of the period. This limited production in the size of building material was reflected in the production of space, moreover, the construction period of 
the buildings could reach decades or even centuries. An example of this is the hundreds of monumental buildings that have put their stamp in the history of architecture. When we look at the structures built today with the same materials, it is seen that their number is decreasing because new materials developed with the Industrial Revolution or developed with production techniques are used more often. With this situation, the departure from architectural tactility has begun to occur.

One of the stimulants that help to perceive the space, sound, just like light, acts by hitting and reflecting on the surfaces in the space and supports people in the sense of hearing and sense of space. Architecture historian Leland M Roth (1943...) explains that architecture can be heard through the suppressed vision (Leland, 2006: 137). In today's world, where spaces are designed with an ocularcentered perspective, it is clear that the perception of space created by sound is more effective in terms of interaction and experience established with space. The subject, who is a spectator with vision, establishes a relationship with hearing and space. Every architectural work, city, street; according to its structure, material, shape and style, it has a unique echo.

Smell, which is one of the stimuli in perceiving the space, is the sense that creates the most permanent memory of the space in human memory. Since the smell is felt without passing through the cognitive filter, the reactions given are emotional intense reactions. Smells provide the ability to take people to memories in a short time, revitalizing an event or place in the mind. "The most permanent memory of any place is often its smell. Each shelter has its own individual home scent. A special scent allows us to re-enter a space that our memory has completely forgotten." (Pallasmaa, 2011: 67).

Another stimulating perception of space is the sense of taste. The fact that the relationship with the space is based on the multi-sensory experience strengthens its ability to be imprinted on one's mind and memory. The sensation that makes it most effective to remember in the senses is the sense of taste along with the smell. These senses form stronger ties with past moments than other senses.

\section{Realization of Questionnaire Studies Through Determined Criteria}

During the determination of the experimental platform of the theoretical research, it was aimed to understand how the consumer shapes the ocular-centric and phenomenological factors in the perception of space while selecting five coffee places in the Beyoglu Region. Therefore, attention was paid to the fact that the criteria of the location evaluation were dominated by the ocular-centric method of one of the selected places, the location evaluation criteria for the other place is designated by the phenomenological method, and the other three places were hybrid spaces containing the evaluation criterion by the ocular-centric and phenomenological method.

In order to obtain more realistic results, a fixed group of twenty people was created from the questionnaires for five coffee places located in Beyoglu region, which have different features, and it was aimed to compare their experiences in these cafes based on each subject. In this comparison made with the questionnaire questions, the features of the space which are perceived in the memory affecting the subjects positively are the perceived space (phenomenological, perceived or hybrid) and the effects of the spaces on the interior design criteria were evaluated.

While creating the subject group, attention was paid to the fact that the determined group was composed of 25-40 age old, university graduate, and middle-income individuals following the general customer base of the selected coffee places. The subject group must be compatible with the target group spending time in the determined coffeehouses to obtain more realistic results. While creating the questions to be asked to the subjects, the aim is to understand which of the spatial features based on ocular-centered and phenomenological elements are in the memory of the subjects and which interior is preferred according to these perception criteria. In the spaces that are evaluated according to the determined criteria, will the users "perceive the cafes with these aspects", "will these effects of the cafes have effects on their senses, experience and behavior", "in which places the subjects feel better" and "is this feeling of well-being determined by the difference of perception of the place?" are the questions for which answers were sought. It was preferred that the questions designated for the questionnaire were open-ended so as not to manipulate the subjects and to learn their unique, personal feelings and thoughts. The participants were asked to compare the effects of the five coffee places determined by the questionnaire. It is aimed to understand whether the places are in the memory of the subjects with their experiences and sensations or functional and visual features. It was questioned which characteristics of the coffee places, which are recorded as positive in the memory of the subjects are effective. Did they feel good and happy because of their characteristics, were intuitive, emotional effects, experiences reasons of preference, what they remember, and what senses they stimulate?

Strong and ever-lasting spaces that affect the subject are those that establish a sensory relationship with the subject and leave traces in her/his memory. For this reason, each venue was first visited by the subjects, and then one month later, personal evaluations about the location experiences were obtained by asking open-ended questions about the five coffee places they visited. As an analysis method, the data are placed in multi-axis diagrams and grouped. The multi-axis diagram (Table 1) was preferred because it facilitates the arrangement and editing of personal expressions.

The ocular-centered approach states that the perception of space should be with sight and reason, and the phenomenological approach should be with the perception of space. For this reason, in the analysis of the questionnaires, the data that remained in the minds of the subjects regarding the coffee places were examined in two main axes: mind, sensation and experience, and vision in four sections. Based on the statements described in the conceptual section of the study and the expressions used by the participants in answering the questionnaire questions, special concepts were created for this study. The places of these concepts in the multi-axis diagram are determined by the scoring system in Table 2 (Erkartal, 2014: 8388). 
Figure 1. Data sections used in multi-axis diagram and questionnaire analysis. Experience + Reason: It consists of profit-oriented features that are experienced with the body without seeing. Experience+Sensation: This section, which includes the phenomenological features of architecture, includes sensations such as movement, hearing, smell, touch, the bond established with the place, the atmosphere effect and the aura of the space. It contains bodily sensations and multi-sensory experiences.

Sight+Reason: It includes rational features such as functionality, modulation, and form-oriented, based on the mind of modern architecture. For this reason, it expresses ocularcentrism. Sight+Sensation: It contains features that evoke strong emotions in the subject, the amount of light, brightness, and the space that the eye considers as a sense organ rather than the eye of the mind, which stimulates the psychological and physical perceptions.

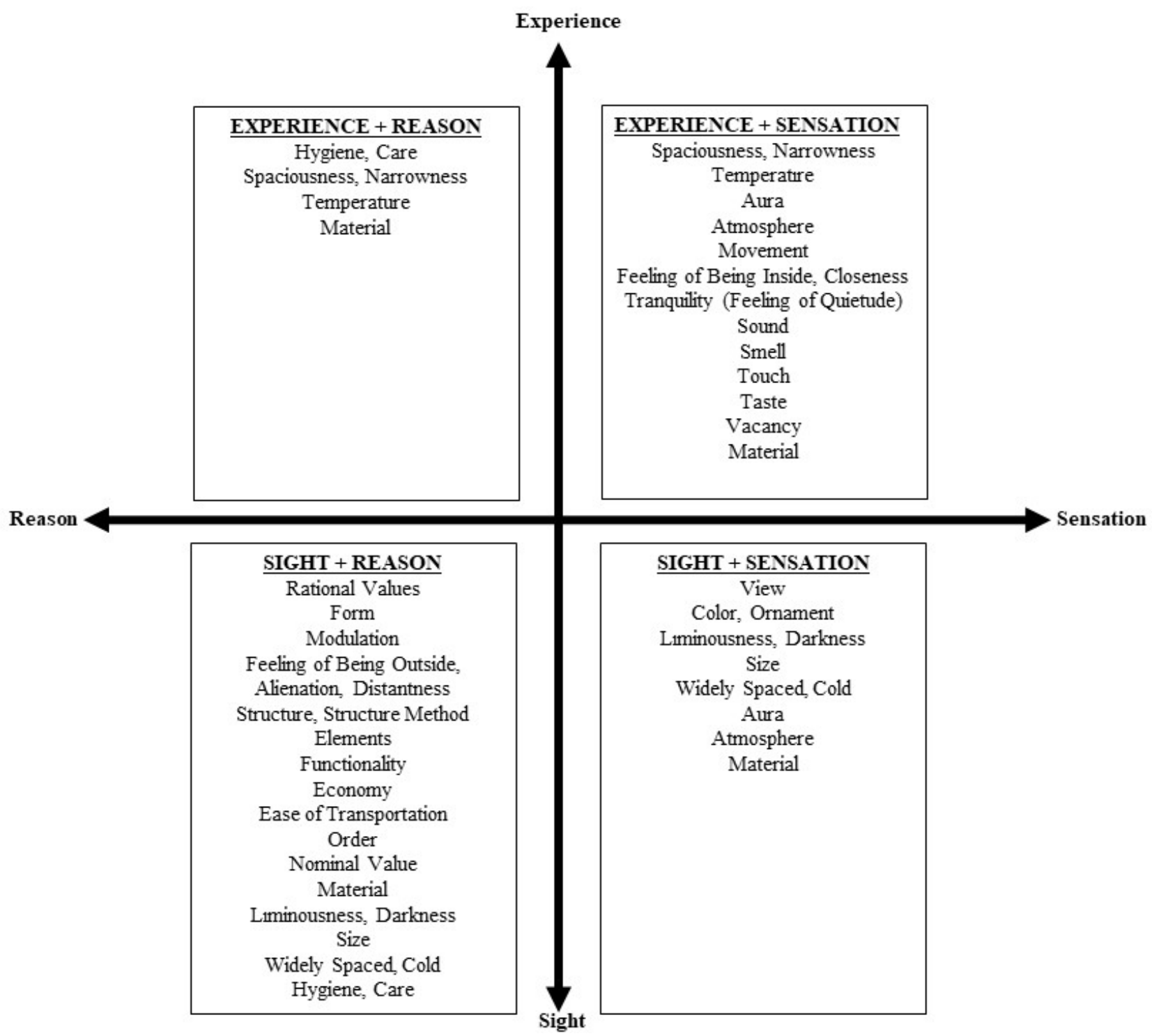

The information obtained from the narrative expression of the subjects were matched with the concepts in table 1 and evaluated with the scoring system.

The concepts listed by the Data Scoring Method determine which of the four sections in the diagram belong to the $0,1,2$ points given. " 0 " means that it does not belong to that section, "1" means that it belongs to that section conditionally, and " 2 " means that it belongs to that section. To evaluate the scored concept, the decision was made taking into account the narrative expression of the subject. It is important to pay attention to the conditional features when evaluating the narratives, for example, if the subject remembers the soundness of the material, it is placed in the reason + sight section, and in the experience + sensation section if the subject recalls the texture felt when she/he touches its surface. 
Table 1. The Concepts Listed By The Data Scoring Method

\begin{tabular}{|c|c|c|c|c|c|}
\hline \multirow{2}{*}{$\begin{array}{c}\text { CONCEPTS USED IN } \\
\text { DESCRIPTION OF THE SPACE }\end{array}$} & \multicolumn{4}{|c|}{ AXIS } & \multirow{2}{*}{$\begin{array}{l}\text { PLACE IN THE } \\
\text { AXIS }\end{array}$} \\
\hline & EXPERIENCE & SENSATION & SIGHT & REASON & \\
\hline $\begin{array}{lll}\text { RATIONAL (RATIO, } & \text { PLAN, } \\
\text { ANGLE) VALUES } & \\
\end{array}$ & 0 & 0 & 2 & 2 & Sight and Reason \\
\hline FORM & 0 & 0 & 2 & 2 & Sight and Reason \\
\hline MODULATION & 0 & 0 & 2 & 2 & Sight and Reason \\
\hline $\begin{array}{l}\text { FEELING OF BEING OUTSIDE, } \\
\text { ALIEANATION, DISTANTNESS }\end{array}$ & 0 & 0 & 2 & 2 & Sight and Reason \\
\hline $\begin{array}{l}\text { STRUCTURE, STRUCTURE } \\
\text { METHOD ELEMENTS }\end{array}$ & 0 & 0 & 2 & 2 & Sight and Reason \\
\hline $\begin{array}{l}\text { FUNCTIONALITY } \\
\text { (PERFORMANCE-USEFULNESS) }\end{array}$ & 0 & 0 & 2 & 2 & Sight and Reason \\
\hline ECONOMY & 0 & 0 & 2 & 2 & Sight and Reason \\
\hline EASE OF TRANSPORTATION & 0 & 0 & 2 & 2 & Sight and Reason \\
\hline ORDER & 0 & 0 & 2 & 2 & Sight and Reason \\
\hline NOMINAL VALUE & 0 & 0 & 2 & 2 & Sight and Reason \\
\hline MATERIAL & 1 & 1 & 1 & 1 & $\begin{array}{l}\text { It will be shaped according } \\
\text { to the relationship with the } \\
\text { material. }\end{array}$ \\
\hline VIEW & 0 & 2 & 2 & 0 & Sensation and Sight \\
\hline COLOR, ORNAMENT & 0 & 2 & 2 & 0 & Sensation and Sight \\
\hline LIGHT-SHADE & 1 & 2 & 2 & 1 & $\begin{array}{l}\text { Sight and Sensation, } \\
\text { Conditional Reason and } \\
\text { Experience }\end{array}$ \\
\hline LUMINOUSNESS-DARKNESS & 0 & 1 & 2 & 2 & $\begin{array}{l}\text { Sight and Reason, } \\
\text { Conditional Sensation }\end{array}$ \\
\hline SIZE & 0 & 1 & 2 & 2 & $\begin{array}{l}\text { Sight and Reason, } \\
\text { Conditional Sensation }\end{array}$ \\
\hline DISTANT COLD & 0 & 1 & 2 & 2 & $\begin{array}{l}\text { Sight and Reason, } \\
\text { Conditional Sensation }\end{array}$ \\
\hline HYGIENE, CARE & 1 & 0 & 2 & 2 & $\begin{array}{l}\text { Sight and Reason, } \\
\text { Conditional Experience }\end{array}$ \\
\hline SPACIOUSNESS-NARROWNESS & 2 & 2 & 0 & 1 & $\begin{array}{l}\text { Experience and Sensation, } \\
\text { Conditional Reason }\end{array}$ \\
\hline TEMPERATURE & 2 & 2 & 0 & 1 & $\begin{array}{l}\text { Experience and Sensation, } \\
\text { Conditional Reason }\end{array}$ \\
\hline $\begin{array}{lcc}\text { AURA (FEELING } & \text { OF } & \text { LIFE } \\
\text { EXPERIENCE, } & \text { TEMPORAL } \\
\text { LAYERS) } & & \\
\end{array}$ & 2 & 2 & 1 & 0 & $\begin{array}{l}\text { Experience and Sensation, } \\
\text { Conditional Sight }\end{array}$ \\
\hline $\begin{array}{lr}\text { ATMOSPHERE } & \text { (SENSE, } \\
\text { EMOTIONAL BOND, MATERIAL } \\
\text { CONFORMITY) } \\
\text { IMPRESSION) (DEEP SHADE) }\end{array}$ & 2 & 2 & 1 & 0 & $\begin{array}{l}\text { Experience and Sensation, } \\
\text { Conditional Sight }\end{array}$ \\
\hline $\begin{array}{lrr}\text { MOVEMENT } & \text { (KINETIK } & \text { AND } \\
\text { MUSCLE } & \text { SENSATION } & \text { ACT } \\
\text { ACTIVITY) } & & \\
\end{array}$ & 2 & 2 & 0 & 0 & Experience and Sensation \\
\hline $\begin{array}{l}\text { FEELING OF BEING } \\
\text { CLOSENESS }\end{array}$ & 2 & 2 & 0 & 0 & Experience and Sensation \\
\hline $\begin{array}{lll}\text { TRANQUILITY } & \text { (FEELING } & \text { OF } \\
\text { QUIETUDE) } & & \\
\end{array}$ & 2 & 2 & 0 & 0 & Experience and Sensation \\
\hline SOUND & 2 & 2 & 0 & 0 & Experience and Sensation \\
\hline SMELL & 2 & 2 & 0 & 0 & Experience and Sensation \\
\hline TOUCH & 2 & 2 & 0 & 0 & Experience and Sensation \\
\hline TASTE & 2 & 2 & 0 & 0 & Experience and Sensation \\
\hline VACANCY (GAP) & 2 & 2 & 0 & 0 & Experience and Sensation \\
\hline
\end{tabular}


The data obtained from the questionnaires were placed in the data sections (table 1) in the multi-axis diagram according to the data scoring method in table 2. The expression, which corresponds to every concept in Table 2, was placed in the appropriate section in Table 1 and it was determined which information belonged to the section in the multi-axis diagram with the data which remains in the memory of the person. The answers given to the open-ended questions asked by the interview method involve the explanation and comparison of the coffee places. The expressions used by examining the expressions were placed in the appropriate section in the multiaxis diagram for each coffee place.

\section{Results and Discussion}

The information obtained from the questionnaires was placed according to the region where it is appropriate in the axes by data scoring method.

Table 2. Evaluation of Coffee Places by Data Scoring Method.

\begin{tabular}{|lclccc|}
\hline Cafeteria & $\begin{array}{c}\text { Experien } \\
+ \\
\text { Sensation }\end{array}$ & $\begin{array}{c}\text { Experience } \\
+ \\
\text { Reason }\end{array}$ & $\begin{array}{c}\text { Sight } \\
+ \\
\text { Reason }\end{array}$ & $\begin{array}{c}\text { Sight } \\
+ \\
\text { Sensation }\end{array}$ & Total Data \\
\hline Space 1 & 172 & 5 & 78 & 27 & 282 \\
\hline Space 2 & 75 & 8 & 76 & 66 & 225 \\
\hline Space 3 & 148 & 6 & 71 & 63 & 288 \\
\hline Space 4 & 33 & 11 & 98 & 29 & 171 \\
\hline Space 5 & 103 & 5 & 79 & 40 & 227 \\
\hline
\end{tabular}

Evaluation of Coffee Places by Data Scoring Method, the data obtained from the subjects were collected and placed in the relevant section for each place. Space1: The place with the highest score of data corresponding to Experience + Sensation, ranked 2nd with the total number of data, perceived by the phenomenological method. Space 2: The place with the highest score of data corresponding to Sight + Sensation, it is a hybrid place. Space 3: The place with the highest total number of data, ranked 2nd corresponding to experience + sensation data number, it is a hybrid place. Space 4: The place with the highest score of data corresponding to Sight+Reason, with the lowest score of data corresponding to experience + sensation and total data number, it is a space perceived by ocularcentrist method. Space 5: It is a hybrid space.

Figure 2. Proportional distribution of coffee places data, data numbers in table 5, percentage distribution in the multi-axis diagram are shown.

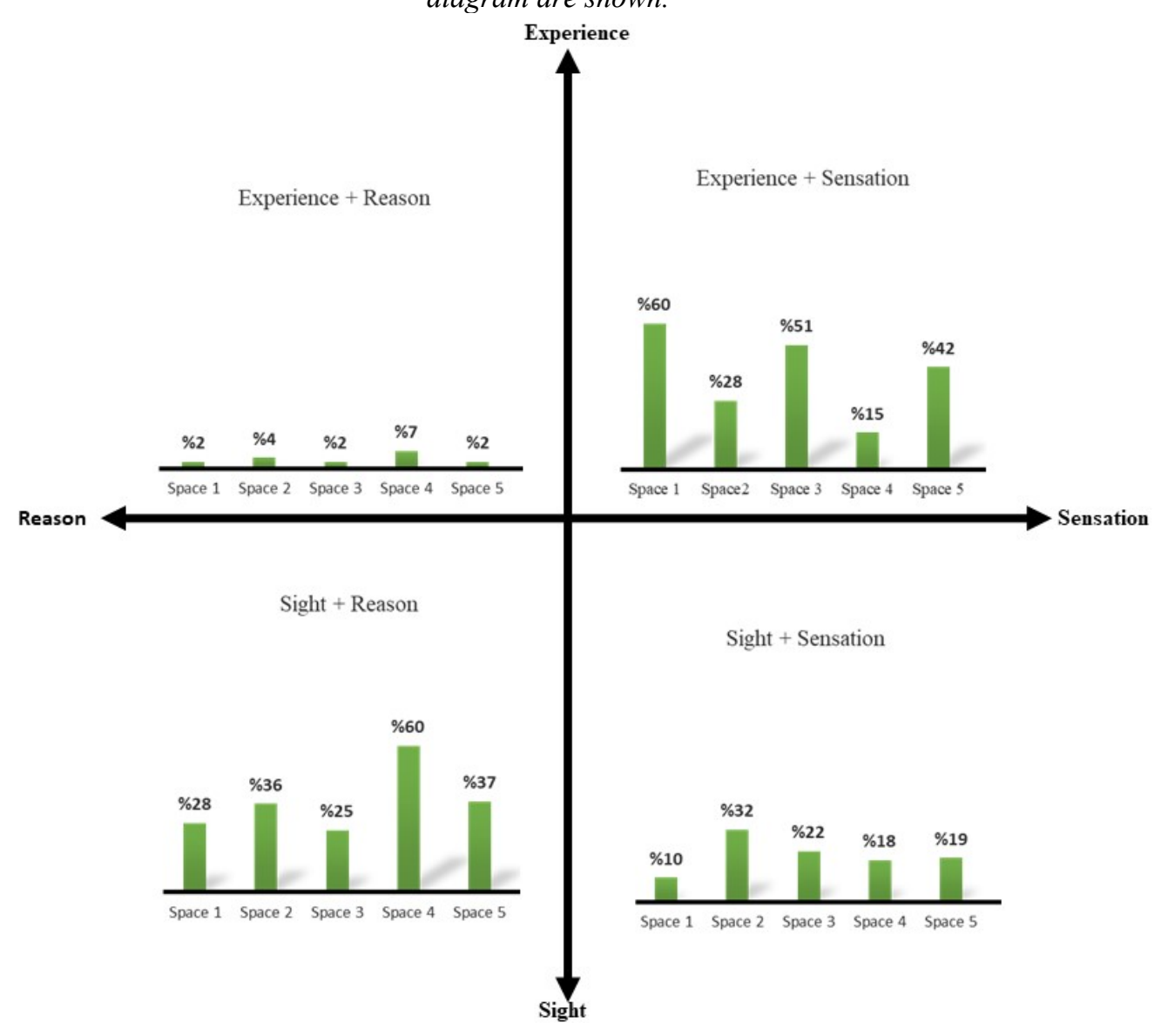


Following the questionnaire studies conducted with a group of twenty people, when the numerical data (Table 3) and rates (Figure 2) for each coffee place are examined, it is seen that the subjects perceive the coffee places in a way that is parallel to the phenomenological and ocular-centric methods;

Space 1; is the space perceived by the phenomenological method. It was the coffee place that had the highest number of data based on "experience + sensation" in the memory of the subjects and ranked 2nd in the total number of data.

Space 2; it is a hybrid space where Pop Art effects are seen. Therefore, many items stimulate sight. As seen from the table as a result of the interviews, it is seen that the number of sight+sensation column numerical data is higher than the other places, and there is a lot of information about the bodily vision related to this place in the memories of the subjects.
Space 3; it is the place that has the most phenomenological element among the hybrid spaces examined. It is ranked in the 1st place with the number of data based on "experience + sensation".

Space 4 ; it is a place that is perceived by the ocularcentered method. It is the place with the lowest total number of data and this data is based on "sight+reason".

Space 5 is a hybrid environment that has the features of the two investigation themes, falling on the second row with its data based on "experience + sensation". The environment benefits from natural substances to create the feeling of an atmosphere. However, the environment also holds the influence of the global system which the industrial-modern-world has imposed.

Figure 3. The primary two cafes in which people felt themselves good and happy When the subjects were asked which are the primary two cafes in which they felt themselves good, "Space 1" was selected as one of the places. When they were asked in which cafe, they feel themselves happy, the answer is again "Space 1". "Space 1" is the place which has the most experience+sensation related data perceived by the phenomenological method.
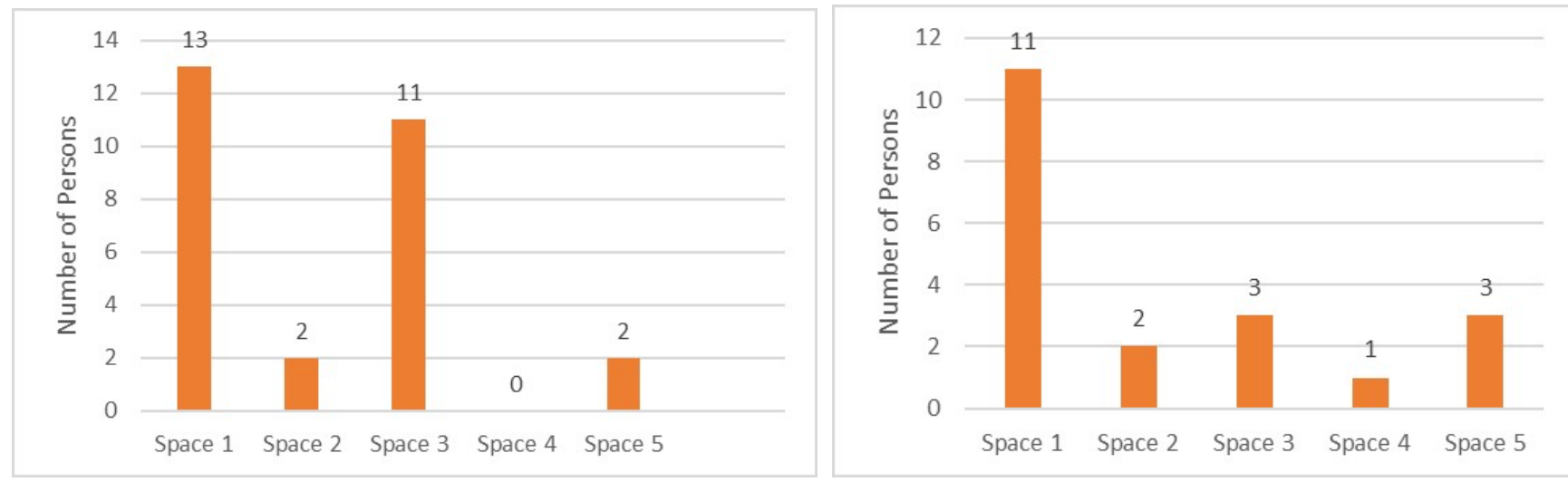

It is seen that more data is remaining in the memory of the subjects regarding the spaces perceived by the phenomenological method, and most of these data are based on "experience + sensation".

\section{Conclusion}

A person perceives the stimuli coming from the surrounding environment with senses and feelings, can make sense of life accordingly and collect memories. Temporary or permanent traces left by the spaces and places on human memory are shaped by the data to be deducted from the space and the place. The degree of influence and numbers of these data define the trace left in memory. For this reason, the reduction of a spatial experience only to visuality has been the target of criticism of all the disciplines working on the notion of space. Figure 2 demonstrates the investigation regarding how the examined spaces are perceived, in terms of phenomenological and ocular-centered methods, by the consumers. In terms of the five coffee places selected in the Beyoglu district of Istanbul, the determination and preferences of consumers of these spaces were determined in light of the ocular-centric and phenomenological methods through the perception of the materials used for the interior design and the selection of the entire space fittings. 
Table 3. Table Regarding the Evaluation of Space Through Phenomenological and Ocular-Centered Methods.

\begin{tabular}{|l|l|l|l|l|}
\hline Space 1 & \multicolumn{1}{|c|}{ Space 2 } & \multicolumn{1}{|c|}{ Space 3 } & Space 5 \\
\hline $\begin{array}{l}\text { The happiest and } \\
\text { well-felt place } \\
\text { perceived by the } \\
\text { phenomenological } \\
\text { method }\end{array}$ & $\begin{array}{l}\text { Hybrid place; } \\
\text { accomodates the } \\
\text { highest number of } \\
\text { ocularcentrist } \\
\text { factors, ranks in the } \\
\text { 3rd place in terms of } \\
\text { the place in which } \\
\text { subjects feel } \\
\text { themselves good and } \\
\text { happy }\end{array}$ & $\begin{array}{l}\text { Hybrid place; } \\
\text { accomodates the } \\
\text { highest number of } \\
\text { factors, ranks in the } \\
\text { 2nd place in terms of } \\
\text { the place in which } \\
\text { subjects feel } \\
\text { themselves good and } \\
\text { happy }\end{array}$ & $\begin{array}{l}\text { The least happy and } \\
\text { well-felt place } \\
\text { perceived by the } \\
\text { ocularcentered } \\
\text { method }\end{array}$ & $\begin{array}{l}\text { Hybrid place; ranks } \\
\text { in the 2nd place in } \\
\text { terms of } \\
\text { accomodating } \\
\text { phenomenologic } \\
\text { factors and ranks 3rd } \\
\text { in terms of the place } \\
\text { in which the subjects } \\
\text { feel themselves good } \\
\text { and happy }\end{array}$ \\
\hline
\end{tabular}

As a consequence of the conducted questionnaires, it has been revealed and determined that the spaces perceived by the phenomenological method have been imprinted in consumer's memory more compared to the ones perceived by the ocularcentric method and the consumers feel better in such spaces and places. When it is evaluated in terms of consumer perception, interior design criteria are related to the aspects mentioned below;

-The space to stimulate other senses such as touch, smell, taste, and hearing in addition to sight, that is, space is experienced multi-sensuously,

-Designing the space to allow different experiences at every turn about movement and time, rather than being designed merely to create visually striking effects,

-Designing the space in harmony with the region where it is located, allowing the heritage, architectural origins and emotional strengths of the building or region to be felt, in other words, to maintain the bond between the street, avenue or neighborhood where the place is located,

-Designing the building in conformity with the climate of the place it is located in, suitable for the position of sun rays,

-Providing that the building preserves and protects the history, genuine life experience traces,

- The place being host to furniture, accessories and architectural elements related to the culture of the region where it is located which are reminiscent in the social and collective memory,

-Bringing the old construction methods and craftsmanship immanent in the original of the building to light, namely protecting authentic values, thus allowing the consumer to connect with the people who lived there in the past,

-Designing the space with an understanding that allows it to be shaped by the life which goes beyond a design understanding that is finished with the construction,

-Using tactile materials based on natural and old construction methods, such as firebrick, solid wood, a natural stone which can be sensed with bare skin, the consumer is ought to feel the hand of the craftsman on each brick and the traces of life experience on each piece of wood. Thus, it will be ensured that the consumer connects with space, perceives the space with

e-ISSN: 2148-2683 physical sensations and experiences suitable for human existence, and integrates with space, which is an achievement of belonging and adoption.

Despite the ocular-centric criticism initiated in the second half of the 20th century, most of the coffee places in Istanbul Beyoglu are still designed by the ocular-centered method under the influence of modernization, globalization and popular culture, and it is seen that there are very few coffee places designed by the phenomenological method. This situation can be acknowledged as a general change process for the globalizing world.

Due to the increasing number of digital platforms in our modus vivendi and the requirements introduced with the COVID-19 pandemic activate numerous new digital social sharing platforms. Connecting to these social sharing platforms, schools, and workplaces from home, provision of the functionality of these through computers from our homes now somehow eliminates the loss of time in traffic or for various reasons, and it seems to save us time. However, we will monitor how long a human being, a social entity, can continue this process with an ocular-centered perception through digital modalities and how it is suitable for human psychology in the coming period.

When museums, exhibitions, historical buildings, concerts, and demonstrations that are opened to visit in a virtual environment are examined, it is seen that they are detached from the essence without the sense of holistic space. This situation, which takes people away from dealing with and interacting with the work of art, also eliminates the emotional bond of the interlocutor because it is only the image of the artwork displayed on the screen. The time spent on the way to a museum or exhibition hall, the experiences lived there, the place you are in, the experiences gained while navigating the corridors are permanent in the human memory. The trip, which is initiated with a click for virtual visits, is subject to visual evaluation only within the limitations of time and space. It will be proportional to the extent to which of these events that are increasingly taking place on social media will leave a trace in our memories, to what extent the details will be remembered in the coming years, to what extent the perception of space which will be examined by 
ocularcentric and phenomenological methods will be affected and changed.

\section{References}

Altıparmakoğlu Sakarya, G., Gürani, Y. (2021). Assessment of the Interaction between Space and Visitor in the Case of the Cité de l'Architecture et du Patrimoine. European Journal of Science and Technology, (21), 341-357.

Aydinlı, S. (2008). Mekan'dan Mekansala: Mekanın zamansallığı, Zamanın mekansallığı. (Haz.: A. Şentürer, Ş. Ural, Ö. Berber, F. Uz Sönmez), s. 150-161, İstanbul: YEM Yayin.

Baymur, F. (1976). Genel Psikoloji. Istanbul: Inkılap Kitabevi. ISBN:9751000972

Bognar, B. (1985). A Phenomenological Approach To Architecture And Its Teaching In the Design Studio, In Dwelling, Place And Environment: Towards A Phenomenolgy of Person and World. ed: Seamon. D. and Mugerauer, R. (eds.) Dordrecht: Martinus Nijhoff Publishers.

Çakıcı Alp, N, Erkan Yazıcı, Y. (2017). Duyuların Mekânsal Deneyimleri Şekillendirmesi: Sagrada Familia Kilisesi. SDÜ ART-E Güzel Sanat Dergisi, 10(19), 55 - 77. e-ISSN: 1308-2698.

Erkartal, Ö.P. (2014). Modern Mimaride Biçimsel Kurguların Sorgulanması ve Dokunsal Mimarlik (Doctoral Thesis). Yıldız Technical University Science Institute, Istanbul.

Gürsoy, D. (2005). Sohbetin Bahanesi Kahve. Istanbul: Oglan Publishing. ISBN: 9789753295192

İnceoğlu, A. (1999). Evin Anlamı Ve Kentlileşme Süreci (Doctoral Thesis). I.T.U. Science Institute, Istanbul.

Kartal, A. N. (2015). Üç (Parantez) Bir anlatı: Ucu açık fenomenolojik bir deşifre (Master's Thesis). I.T.U. Science Institute, İstanbul.

Leland, M. R. (2006). Mimarlığın Öyküsü, Öğeleri ve Anlamı. Translated by Ergün Akça. Istanbul: Kabalcı Publishing. ISBN: 978-605-5272-49-4

Loos, A. (2018). Mimarlık Üzerine. Translated by Alp Tümertekin, Nihat Ülner. Istanbul: Janus. ISBN: 9786058495500

Morgan, C. T. (1981). Psikolojiye Giriş Ders Kitabı. Translated by Rükzan Eski, Sirel Karakaş. Ankara: Hacettepe University Psikoloji Department Publishing. ISBN: 9758890705.

Ojalvo, R. (2012). Arzu Mimarlığı Mimarlığı Düşünmek ve Düşlemek. Istanbul Iletişim Publishing. ISBN: 9789750511264

Pallasmaa, J. (2011). Tenin Gözleri. Translated by Aziz Ufuk Kılıç. Istanbul: YEM Publishing. ISBN: 6058119154.

Panofsky, E. (1991), Perspective as Symbolic Form. New York: Zone Books. ISBN:0-942299-52-3; http://tems.umn.edu/pdf/Erwin\%20Panofsky\%20$\% 20$ Perspective $\% 20$ as\%20Symbolic\%20Form.pdf

Sharr, A. (2007). Mimarlar için Heidegger. Translated by Volkan Atmaca. Istanbul: Yem Publishing. ISBN: 9789944757782

Soykan, Ömer Naci. (2008). Uzam Bellek Bağlantısı Açısından Mimarlığa Bakış Zaman - Mekân, 34-39. İstanbul: Yem Yayınları.

Turgay, O. (2018). Deneyimlenen Mekânın Bir Anlam Olarak Bellekte Varlığının Sürdürülmesi. Tasarım ve Bellek Temalı Ulusal Mekân Tasarımı Sempozyumu. 156-165. Trabzon, Turkey.
Zevi, B. (2015). Mimarlığı Görebilmek. Translated by Alp Tümertekin. Istanbul: Daimon Publishing. ISBN: 9786058510876. 